\title{
ДО ВИВЧЕННЯ ФАУНИ КОМАХ ДЕНДРОТЕЛЬМ В БУКОВОМУ ПРАЛІСІ УГОЛЬСЬКОГО МАСИВУ КАРПАТСЬКОГО БІОСФЕРНОГО ЗАПОВІДНИКА
}

\author{
Яремчук М.Ю.
}

До вивчення фауни комах дендротельм в буковому пралісі Угольського масиву Карпатського біосферного заповідника. -М.Ю. Яремчук. - Фауна облігатних жителів дендротельм букових пралісів складає 8 видів, які населяють мікроводойми на стадї личинки: Prionocyphon serricornis (Mull.), Elodes marginata Fabr., Cyphon coarctatus Payk. (Scirtidae, Coleoptera); Anopheles claviger (Meigen), Anopheles plumbeus Steph., Ochlerotatus geniculatus (Oliv.) (Culicidae, Diptera), Dasyhelea flavifrons (Guer.) (Ceratopogonidae, Diptera), Metriocnemus cavicola Kieffer (Chironomidae, Diptera).

Ключові слова:буковий праліс, Карпатський біосферний заповідник, дендротельми.

Адреси: Ужгородський національний університет, вул. Волошина, 32, Ужгород, 88000 Україна, е-таіl: jaremchukmukola@yahoo.com

To the study of insects fauna of aquatic tree-holes in beech virgin forest of the Uholka massif of the Carpathian Biosphere Reserve. - M.Yu. Jaremchuk. - The fauna of obligate inhabitants of dendrothelms in beech primeval forests includes 8 species: Prionocyphon serricornis (Mull.), Elodes marginata Fabr., Cyphon coarctatus Payk. (Scirtidae, Coleoptera); Anopheles claviger (Meigen), Anopheles plumbeus Steph., Ochlerotatus geniculatus (Oliv.) (Culicidae, Diptera), Dasyhelea flavifrons (Guer.) (Ceratopogonidae, Diptera), Metriocnemus cavicola Kieffer (Chironomidae). They inhabit the micro-reservoirs at the larval stage.

Key words: beech virgin forest, Carpathian biosphere reserve, dendrothelms.

Address: Uzhhorod National University, 32 Voloshyna str., Uzhhorod, 88000 Ukraine; e-mail: jaremchukmukola@yahoo.com

\section{Вступ}

Природні ліси, зокрема букові, характерризуються великою кількістю екологічних ніш, або оселищ, що є передумовою високого фауністичного різноманіття. Однією із особливостей пралісів $€$ наявність старих дерев. В Угольському масиві дерева першого ярусу досягають 300-500 річного віку. Відповідно кожне дерево містить певну кількість мікрооселищ.

Серед різноманіття мікрооселищ важливими для розуміння процесів, що забезпечують функціонування екосистеми, $\epsilon$ дендротельми - особливі структури на деревах, заповнені водою та населені спеціалізованими комплексами комах та інших безхребетних тварин (Kraus et al. 2016).

Дослідження дендротельм, їхнього стану та видового складу фауни $\epsilon$ вкрай важливим для збереження біорізноманіття досліджуваного регіону. Деревні «водойми», акумулюючи воду, утворюють сприятливе середовище для розвитку лісової фауни. Дендротельми можуть розглядатися як природні структури для забезпечення довгострокового виживання певних видів тварин - комах, земноводних, ссавців та птахів.

Розуміння факторів, що впливають на виникнення та поширення природніх дупел дерев, їх зв'язок з біорізноманіттям, в кінцевому рахунку дасть змогу оцінити роль дендротельм у збереженні біологічного різноманіття. А збереження природніх дупел в загальній практиці лісового господарства може допомогти зменшити втрати лісового біорізноманіття, тоді як моніторинг дендротельм може виявитися додатковим інструментом для оцінки стану біорізноманіття в лісах (Gossner et al. 2016).

У теперішніх умовах керування лісовим господарством Закарпаття стає дедалі актуальнішим питання ролі дендротельм та їхній зв'язок 3 біорізноманіттям. Даний напрямок досліджень слабо вивчений на території Українських Карпат, що є особливо актуально дивлячись на тенденцію напрямку вивчення збереження лісів в цілому. 


\section{Матеріал і методика}

Фауну дендротельм вивчали на 10-ти гектарній постійній пробній площі, яка була закладена у 2010 році в буковому пралісі Угольського масиву Карпатського біосферного заповідника. Пробна площа розташована в південній частині масиву, висота над рівнем моря - 700-800 м. Ділянка вкрита пралісом, угруповання Fagetum dentariosum i F. asperulosum (Sukahriuk 2006). Склад насаджень пралісу: бук європейський 97\%, 3 домішками клена-явора (Acer pseudoplatanus) та гостролистого (A. platanoides) (по 2,1\%), ясен (Fraxinus excelsior) $(0,6 \%)$ та в'яз шорсткий (Ulmus glabra) $(0,4 \%)$ (Commarmot et al. 2013).

Дослідження проводилися протягом вегетаційного періоду 2017-2018 років.

Для ідентифікації виготовлялися тимчасові та постійні препарати. Для просвітлення об'єктів використовували гліцерин та рідину Форра (гумміарабікову суміш). Ідентифікацію проводили під світловим бінокулярним стереоскопічним мікроскопом Krystal Conus. Макрофотографії отримували 3 допомогою цифрової камери Sigeta M3CMOS 10000 .

\section{Результати та висновки}

В результаті наших досліджень було виявлено та опрацьовано 365 природніх дендротельм.

В результаті вивчення дендротельм букового пралісу виявлено 6 їх типів: мікроводойма в дуплі в стовбурі дерева; водойма в розвилці дерева; мікроводойма при основі кореня; мікроводойма на зламі дерева; мікроводойма на зламі стовбура живого дерева, мікроводойми утворені на місцях місцях перелому центрального стовбуру та зрізах (пеньках). Середня щільність дендротельм у буковому пралісі становить близько 36,5 на 1 гектар (365 на 10 га).

Фауна облігатних жителів дендротельм букових пралісів складає 8 видів, які населяють мікроводойми на стадії личинки. Систематично зареєстровані види відносяться до 2 рядів Твердокрилі і Двокрилі.

Із представників ряду твердокрилі (Coleoptera), зареєстровано 3 види 3 родини трясовинники (Scirtidae) - Prionocyphon serricornis (P.W.J. Muller, 1821), Elodes marginata Fabricius, 1798, Cyphon coarctatus Paykull, 1799.

Ряд двокрилі (Diptera) представлений п'ятьма видами із трьох родин: родина Culicidae - Anopheles claviger (Meigen, 1804), Anopheles plumbeus Stephens, 1828, Ochlerotatus geniculatus (Olivier, 1791); родина Ceratopogonidae Dasyhelea flavifrons (Guerin, 1833); родина Chironomidae - Metriocnemus cavicola Kieffer, 1921.

Домінуючими за кількістю особин личинок облігатних жителів, виявилися Metriocnemus cavicola (45\%) i Prionocyphon serricornis (28\%).

\section{Подяки}

Дослідження виконувалися в рамках спільного українсько-швейцарського проекту «Kooperation in der Waldforschung Ukraine-Schweiz Urwälder als Referenz für die Artenvielfalt in Schweizer Naturwaldreservaten».

Особливу важливу допомогу у визначенні матеріалу було надано професором Східноєвропейського університету, д.б.н. К.Б. Сухомлін, за що автор висловлює щиру подяку.
COMMARMOT, B., BRÄNDLI, U.-B., HAMOR, F., LAVNYY, V. (2013) Inventory of the Largest Primeval Beech Forest in Europe. A SwissUkrainian Scientific Adventure. Birmensdorf, Swiss Federal Research Institute WSL; Ukrainian National Forestry University, L'viv; Carpathian Biosphere Reserve, Rakhiv.

GOSSNER, M.M., LADE, P., ROHLAND, A., SICHARDT, N., KAHL, T., BAUHUS, J., WEISSER, W.W., PETERMANN, J.S. (2016) Effects of management on aquatic tree-hole communities in temperate forests are mediated by detritus amount and water chemistry. Journal of Animal Ecology, 85: 213-226.

doi: 10.1111/1365-2656.12437

KRAUS, D., BÜTLER, R., KRUMM, F., LACHAT, T., LARRIEU, L., MERGNER, U., PAILLET, Y., RYDKVIST, T., SCHUCK, A., WINTER, S. (2016) Catalogue of tree microhabitats. Reference field list. Integrate+ Technical Paper.

SUKHARIUK, D.D. (2006) Bukovi lisy Karpatskoho biosfernoho zapovidnyka (poshyrennia, tsenotychna struktura ta monitorynh). Scientific Bulletin of Uzhhorod University, Series Biology, 19: 91-95. 